\title{
SELEKSI GALUR DARI POPULASI F4 KEDELAI YANG TAHAN TERHADAP PENYAKIT MOSAIK (SOYBEAN MOSAIC VIRUS) DAN BERDAYA HASIL TINGGI
}

\author{
Wuye Ria Andayanie \& Praptiningsih Gamawati Adinurani \\ Universitas Merdeka Madiun \\ Jln Serayu no 79 Madiun \\ Email: wuye_andayanie@yahoo.com
}

\begin{abstract}
Soybean lines selection of F4 population resistant to soybean mosaic disease (Soybean mosaic virus) with high yield. The soybean breeding program is usually not purposedly done for resistance to Soybean mosaic virus (SMV) but rather for crop yields. The experiment was aimed to obtain soybean lines of F4 population resistant to soybean mosaic disease with high yield. F2-F4 plants that have been inoculated with the T isolate of SMV one week after planting were selected by the pedigree in the screen house. The result indicated eight F4 populations (Wilis x L. Temanggung; Wilis x L. Jombang; Wilis x Pangrango; Wilis x PI 200485; Gepak Kuning x L. Jombang; Gepak Kuning x L. Temanggung; Gepak Kuning x Malabar; Gepak Kuning x PI 200485) produced medium seed size (from 9.84-10.26 g 100/seeds). Gepak Kuning x Mlg 3288 showed more resistant than Gepak Kuning x PI 200485. The seed produced by Gepak Kuning x PI 200485 was 1.97 ton/ha. There were no F4 populations that had higher yield and bigger seed size than Gepak Kuning x PI 200485 even though they were moderately resistant to SMV. Therefore, these lines of Gepak Kuning x Mlg 3288 and Gepak Kuning x PI 200485 might provide exellent sources to develop a new variety that resistant to SMV and of high yield.
\end{abstract}

Key words: high yield, resistance, soybean, Soybean Mosaic Virus

\section{ABSTRAK}

Seleksi galur dari populasi F4 kedelai yang tahan terhadap penyakit mosaik (Soybean mosaic virus) dan berdaya hasil tinggi. Program pemuliaan kedelai tidak ditujukan pada ketahanan terhadap Soybean mosaic virus (SMV) tetapi lebih diarahkan terhadap hasil yang tinggi. Penelitian ini bertujuan untuk memperoleh galur-galur dari populasi F4 tahan SMV dan berdaya hasil tinggi. Tanaman F2-F4 diinokulasi dengan SMV isolat T dan diseleksi dengan metode pedigri di rumah kasa. Hasil penelitian menunjukkan bahwa delapan dari populasi F4 (Wilis x L. Temanggung; Wilis x L. Jombang; Wilis x Pangrango; Wilis x PI 200485; Gepak Kuning x L. Jombang; Gepak Kuning x L. Temanggung; Gepak Kuning x Malabar; Gepak Kuning x PI 200485) mempunyai bobot biji sedang (9,84-10,26 g/100 biji). Gepak Kuning x Mlg 3288 lebih tahan terhadap SMV dibandingkan Gepak Kuning x PI 200485. Gepak Kuning x PI 200485 memiliki hasil 1,97 ton/ha. Tidak ada satupun populasi F4 yang diuji mempunyai hasil dan ukuran biji lebih besar dari populasi Gepak Kuning x PI 200485, meskipun agak tahan terhadap SMV. Oleh karena itu, galur-galur dari populasi Gepak Kuning x Mlg 3288 dan Gepak Kuning x PI 200485 memberikan peluang untuk dikembangkan menjadi varietas unggul kedelai tahan SMV dan berdaya hasil tinggi.

Kata kunci: hasil tinggi, kedelai, ketahanan, Soybean Mosaic Virus

\section{PENDAHULUAN}

Varietas berdaya hasil tinggi masih digunakan sebagai inovasi teknologi budidaya andalan untuk meningkatkan produktivitas per satuan luas. Produksi kedelai dalam negeri belum mampu memenuhi kebutuhan sendiri, padahal potensi pengembangannya di dalam negeri sangat bagus. Produksi kedelai tahun 2013 angka sementara (ASEM) sebesar 780,16 ribu ton biji kering atau turun sebesar 62,99 ribu ton $(7,47 \%)$ dibanding tahun 2012 (Adie \& Krisnawati, 2013; Badan Pusat Statistik, 2013). Penyakit mosaik kedelai yang disebabkan oleh Soybean mosaic virus (SMV) merupakan salah satu kendala utama pada pertanaman kedelai di Indonesia. Varietas kedelai tahan SMV dan berdaya hasil tinggi sebenarnya lebih mudah diterapkan ke petani dan ramah lingkungan. Namun begitu, saat ini pemuliaan diarahkan untuk mendapatkan varietasvarietas kedelai yang berdaya hasil tinggi, bukan untuk mendapatkan varietas yang tahan terhadap SMV. Erosi genetik yang makin meningkat terhadap plasma nutfah memerlukan perhatian lebih besar terhadap plasma nutfah yang ada, terutama dalam hal ini adalah varietasvarietas kedelai lokal. Oleh karena itu, tingginya 
keanekaragaman plasma nutfah kedelai memiliki aspek yang sangat penting untuk dipertahankan.

Badan Litbang Pertanian telah melepas beberapa varietas unggul kedelai. Meskipun di lapangan 60\% petani masih menggunakan varietas Wilis. Hasil penelitian yang lain menunjukkan varietas unggul telah terinfeksi oleh SMV. Infeksi SMV sejak awal pertumbuhan akan menyebabkan biji terinfeksi. Jika biji tersebut digunakan untuk benih, maka virus tersebut akan aktif setelah benih disemai. Tanaman sehat, jika terinfeksi pada fase generatif (Erliana, 2010; Andayanie et al., 2011b; Andayanie, 2012a, 2012b). Di Jawa Timur intensitas penyakit ini mencapai 13,42-30,10\%. Saat ini upaya pengendalian dilakukan dengan sortasi benih, meskipun hasilnya belum memuaskan. Oleh karena itu, tanaman dan benih yang sehat belum jaminan bebas dari virus tersebut (Andayanie et al., 2011a).

Program pemuliaan tanaman untuk ketahanan terhadap penyakit memerlukan sumber gen sebagai bahan utama pembentukan populasi dasar. Hal ini dilakukan agar program pemuliaan dilakukan lebih terarah, efektif dan efisien (Asadi et al., 2005). Infeksi SMV menyebabkan permukaan daun tidak rata dengan gambaran mosaik dan klorosis, kadang daun mengecil. Tanaman terinfeksi tidak selalu menampakkan gejala, bahkan nampak bervariasi, tergantung saat infeksi dan kondisi lingkungannya. Virus ini menyebabkan biji mottle (burik) dan non mottle, sehingga kenampakan biji tidak dapat dijadikan jaminan bebas virus (Andayanie, 2012b).

Hampir seluruh varietas yang dilepas di Korea Selatan tahan terhadap 3 strain SMV yaitu G1, G4, dan G7 (Ma et al., 2004). Uji ketahanan terhadap galur generasi lanjut lebih difokuskan pada penyakit, meskipun pengamatan juga dilakukan untuk ketahanan terhadap beberapa jenis hama utama seperti, pengisap polong, ulat grayak dan cut worm (Balitkabi, 2012). Tanaman kedelai yang terserang virus saat usia lanjut menurunkan kandungan protein dan lemak serta berat polong (Barmawi et al., 2009; Arifin, 2013).

Hasil penelitian sebelumnya menunjukkan bahwa penyakit mosaik kedelai salah satunya disebabkan oleh SMV yang terbawa melalui benih. Penularan lewat benih ini akan menghasilkan intensitas awal, selanjutnya diikuti penularan sekunder oleh vektornya. Kajian perkembangan penyakit mosaik kedelai di lapangan menunjukkan bahwa intensitas penyakit dan laju infeksi, masing-masing ditentukan oleh intensitas penyakit pada awal $\left(\mathrm{X}_{0}\right)$ dan vektor (Andayanie et al., 2011b).

Pengendalian SMV dengan menggunakan varietas tahan sejalan dengan rencana strategis Balitkabi 2009-2014 tentang program pemuliaan kedelai untuk ketahanan terhadap cekaman biotik. Masalah utama yang dihadapi adalah dari 191 aksesi kedelai yang telah diuji hanya diperoleh tujuh asesi kedelai (Lokal Jombang, Mlg 3288, Lokal Temanggung, Malabar, Pangrango, PI 200485, M8Grb 44) dengan kategori sangat tahan SMV secara visual dan bereaksi negatif dengan reaksi RTPCR serta mempunyai penampakan agronomis yang baik. Sepasang universal primer mengamplifikasikan fragmen DNA berukuran sekitar 1687 bp pada posisi 4176 sampai 5560 (Kim et al., 2004; Somowiyarjo, 2004; Hwang et al., 2011; Andayanie \& Adinurani, 2013a, 2013b). Sepasang oligonukleotida yaitu universal primer (Sprimer (F):5' GGNAAYAAYAG YGGNCARCC3' dan (M4) (R): 5' GTTTTCCCA GTCACGAC3' dirancang untuk mengamplifikasikan fragmen DNA berukuran sekitar 1687 bp (Kim et al., 2004; Somowiyarjo, 2004; Hwang et al., 2011; Andayanie \& Adinurani, 2013a) Sepasang primer tersebut dirancang untuk gen $\mathrm{CP}$ dan Non Coding Region ujung 3 anggota famili Potyviridae (Chen et al., 2001).

Asesi tahan tersebut akan digunakan sebagai sumber gen dari sepasang tetua homozigot pada persilangan pedigri, sehingga diperoleh generasi F1 yang seragam. Generasi F2 yang bersegregasi diperoleh dengan penyerbukan sendiri. Pemilihan galur dilakukan pada generasi awal (F2), terutama untuk menyeleksi ketahanan terhadap SMV. Galur F2-F4 ini sebagai persiapan untuk memperoleh galur tahan SMV berdaya hasil tinggi yang diseleksi di lapangan. Komponen hasil pada program pemuliaan tanaman bermanfaat untuk menentukan arah seleksi yang dilaksanakan. Penelitian ini dilakukan dengan tujuan mendapatkan galur-galur dari populasi $\mathrm{F} 4$ untuk pengembangan varietas unggul kedelai tahan SMV dan berdaya hasil tinggi.

\section{METODE PENELITIAN}

Tempat dan Waktu. Penelitian ini dilaksanakan di LPPT dan Laboratorium Genetika Universitas Gadjah Mada Yogyakarta serta di rumah kasa di Desa Jenggrik, Kecamatan Kedunggalar, Kabupaten Ngawi mulai bulan Maret 2013 sampai April 2014.

Penelitian Pendahuluan. Penelitian pendahuluan menunjukkan SMV isolat T dari Kabupaten Ngawi, Jawa Timur lebih virulen dibandingkan isolat $\mathrm{Y}$ dari Gunung Kidul, Yogyakarta. Selain itu telah diperoleh genotip tahan terhadap SMV isolat T dengan cara: 1) evaluasi 191 asesi; 2) reevaluasi asesi; 3) uji konfirmasi asesi. Dengan tahapan ini diketahui tujuh genotipe nampak sehat secara visual terhadap SMV isolat T dari Jawa Timur dan bereaksi negatif dengan uji Indirect ELISA, reaksi RT-PCR. Target mempunyai ukuran 
sekitar 1687 bp dengan marker DNA Ladder $1 \mathrm{~kb}$ (Gambar 1). Penampilan agronomisnya mempunyai bobot 100 biji lebih besar ( $\pm 10 \mathrm{~g} / 100$ biji). Genotipe tersebut terdiri atas: Lokal Jombang (register 3585), Mlg 3288 (register 3805), Lokal Temanggung (register 4472), Malabar (register 3851), Pangrango (register 4116), M8 Grb 442 (register 4498), PI 200485 (register 4554), sedangkan Wilis (register 3460) secara visual rentan dan bereaksi positif dengan reaksi RT-PCR (Gambar 1), meskipun penampilan agronomisnya baik ( $\pm 10 \mathrm{~g} / 100$ biji) (Andayanie \& Adinurani, 2013a). Asesi plasma nutfah tersebut merupakan koleksi dari BB Biogen, Bogor.

Produksi Galur F2. Tujuh genotipe telah diidentifikasi sangat tahan terhadap SMV dan digunakan sebagai tetua tahan. Genotipe atau tetua tahan diperoleh melalui evaluasi dan reevaluasi plasma nutfah serta uji konfirmasi genotipe tahan SMV. Tetua tahan tersebut terdiri atas: Lokal Jombang, Mlg 3288, Lokal Temanggung, Malabar, Pangrango; PI 200485; M8Grb 44. Varietas unggul nasional yang digunakan sebagai tetua rentan yaitu Gepak Kuning agak tahan terhadap Aphis sp. (Pusat Penelitian dan Pengembangan Tanaman Pangan, 2010) dan Wilis (register 3460) rentan terhadap Soybean stunt virus dan Soybean mosaic virus (Asadi \& Dewi, 2010; Andayanie et al., 2011a; Andayanie, 2012b). Hasil kombinasi genotipe tahan dan varietas unggul nasional disilangkan sebanyak 14 kombinasi persilangan. Masing masing tetua tersebut mempunyai bunga berwarna ungu. Lokal Jombang, Mlg 3288, Lokal Temanggung, Malabar, Wilis dan M8Grb 44, PI 200485, Pangrango, Gepak Kuning mempunyai warna bulu coklat. sedangkan Wilis warna bulu coklat tua. Oleh karena itu tanaman F1 akan mempunyai bulu coklat. Tanaman dilakukan perawatan sampai diperoleh biji (F1). Biji F1 hasil persilangan di atas ditanam untuk mendapatkan biji F2. Persilangan antara tetua berbunga dan berbulu sama dianalisa penampilan tanaman yang terdiri atas bentuk, warna dan tipe daun. Jika penampilan sama dengan tetua betina berarti persilangan gagal. Persilangan yang berhasil dan sifat-sifat agronomi serta komponen hasil terbaik dari masing-masing kombinasi persilangan dipertahankan sampai panen. Biji-biji F1 setiap kombinasi persilangan ditanam untuk mendapatkan biji F2.

Seleksi Galur F2-F4 dengan Seleksi Pedigri. Galur F2-F4 diseleksi dengan metode pedigri. Biji F2 sebanyak 1400 biji (100 biji/populasi) ditanam dalam polibag $10 \mathrm{~kg}$ (4 biji/pot), selanjutnya dipilih 2 tanaman/ pot yang nampak sehat. Sehingga jumlah biji F2 700 biji (50 biji/populasi). Tanaman diinokulasi secara mekanik dengan SMV isolat T dari Jawa Timur saat 7 Hari setelah tanam (HST). Daun ke-3 dari masingmasing tanaman ditaburi dengan bubuk Karborundum 400 Mesh dan digosok pelan-pelan supaya jaringan daun tidak rusak. Selanjutnya disemprot dengan air dan diinokulasi dengan isolat SMV. Inokulasi dilakukan dengan menggosokkan sap SMV pada daun ke 3

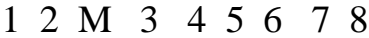

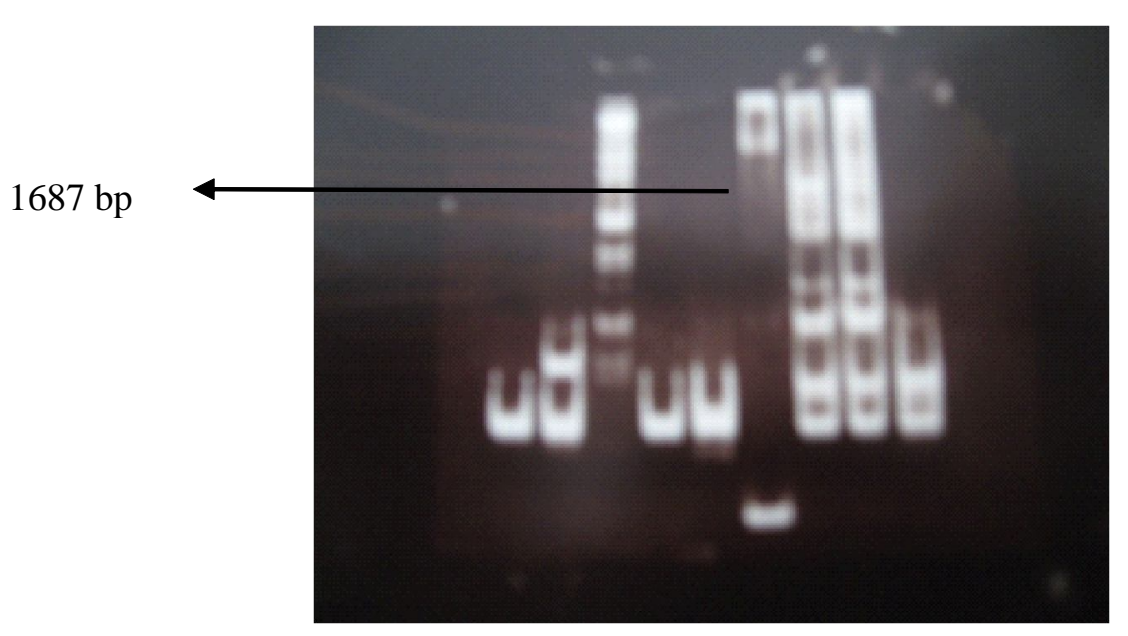

Gambar 1. Fragmen DNA hasil amplifikasi RT-PCR menggunakan primer Universal untuk identifikasi SMV dari isolat T. Lajur 1: L. Jombang; 2: Mlg 3288; 3: L. Temanggung; 4. Malabar; 5: Pangrango; 6: Wilis; 7: PI 200485; 8: M8 Grb 44; M: DNA Ladder $1 \mathrm{~kb}$ sebagai marker (Promega, UK) (Andayanie \& Adinurani, 2013) 
tersebut. Gejala mosaik akan nampak \pm 12 Hari setelah inokulasi (HSI).

Penilaian tingkat serangan SMV dilakukan 12 HSI pada masing-masing kombinasi persilangan berdasarkan skoring yang dikemukakan oleh Sumardiyono, 2011 (komunikasi pribadi) (Tabel 1). Intensitas serangan dihitung berdasarkan rumus (Campbell \& Madden, 1990) :

$$
\mathrm{KP}=\frac{\sum(\mathrm{n} \times \mathrm{v})}{\mathrm{N} \times \mathrm{Z}} \times 100 \%
$$

$\mathrm{KP}=$ keparahan $\operatorname{SMV}(\%)$

$\mathrm{n}=$ jumlah sampel untuk setiap kategori serangan

$\mathrm{v}=$ nilai skor untuk kategori serangan

$\mathrm{N}=$ jumlah sampel tanaman yang diamati

$\mathrm{Z}=$ nilai skor tertinggi (4)

Kombinasi persilangan dengan prosentase keparahan gejala 0-25\% dipertahankan sampai panen dan diteruskan pada evaluasi pengujian berikutnya. Galur-galur F2 dari masing-masing persilangan dengan metode pedigri yang telah diseleksi dipanen untuk diseleksi kembali pada musim berikutnya. Seleksi ini dilakukan dengan cara yang sama hingga diperoleh biji F4. Biji terpilih dipersiapkan untuk ditanam kembali di lapangan dan diuji kembali keparahan penyakit, sifatsifat agronomi dan komponen hasilnya.

\section{HASIL DAN PEMBAHASAN}

Produksi Galur F2. Biji F1 dari 14 kombinasi persilangan yaitu Lokal Jombang, Mlg 3288, Lokal Temanggung, Malabar, Pangrango; PI 200485, M8Grb 44 dengan varietas unggul nasional (Wilis dan Gepak Kuning) menghasilkan biji antara 18-159 biji setiap kombinasi persilangan. Kombinasi persilangan yang memberikan hasil biji terbanyak adalah persilangan antara Gepak Kuning dan Mlg 3288 dengan kisaran 34159 biji.
Produksi biji F2 sebanyak 2160-14326 biji diperoleh dari biji F1 ditanam pada musim berikutnya. Biji F2 dari setiap populasi dipilih yang nampak sehat atau tahan sampai bergejala sangat ringan terhadap SMV untuk seleksi pedigri dirumah kasa, sehingga peluang untuk mendapatkan galur-galur yang berdaya hasil tinggi dan tahan terhadap SMV lebih besar. Biji F3 terpilih di tanam kembali untuk diseleksi dengan cara yang sama. Lima puluh galur F4 per populasi (dengan kategori tahan sampai agak tahan) atau total 700 galur dari seleksi pedigri disiapkan untuk pengujian ketahanan terhadap SMV dan karakter agronomis serta komponen hasilnya.

\section{Pembentukan Galur-Galur dari Populasi F4 Tahan SMV dan Berdaya Hasil Tinggi melalui Metode} Seleksi Pedigri. Seleksi dengan metode pedigri dimulai pada generasi F2. Populasi F2-F4 menghasilkan 563 galur/tanaman. Galur-galur pada setiap tanaman dipilih berdasarkan tingkat keparahan penyakit $0-25 \%$ dengan kriteria tahan sampai agak tahan dari setiap populasi. Kombinasi persilangan dari rata-rata populasi F4 keparahan penyakit berdasarkan gejala visual tergolong kriteria sehat sampai agak rentan (0-30,65\%). Seleksi galur dari populasi F4 Gepak Kuning x Mlg 3288; Gepak Kuning x Malabar, masing-masing tingkat keparahan penyakit $0 \%$ dengan kriteria tahan. Hasil ini diikuti persilangan Gepak Kuning x PI 200485; Gepak Kuning x M8Grb 44, masing-masing rata-rata tingkat keparahan 5,11\%; 6,98\% dengan kriteria agak tahan. Populasi Wilis x Malabar; Gepak Kuning x L. Temanggung, dan Gepak Kuning x L. Jombang tergolong kriteria agak rentan, masing-masing dengan rata-rata keparahan penyakit 31,23\%; 30,65\%; 30,07\% (Tabel 2).

Enam dari 11 persilangan memperlihatkan kriteria tingkat serangan tahan sampai agak tahan, serta memiliki penampilan agronomis lebih dengan kisaran 9,84-10,29 g dibandingkan varietas unggul nasional

Tabel 1. Penilaian gejala serangan Soybean Mosaic Virus (SMV)

\begin{tabular}{clc}
\hline Skor serangan & \multicolumn{1}{c}{ Gejala } & Tingkat ketahanan \\
\hline 0 & Daun sehat & Tahan \\
1 & Gejala mosaik & Agak tahan \\
2 & Gejala mosaik dengan ukuran daun mengecil & Agak rentan \\
3 & Gejala mosaik dengan ukuran daun mengecil dan & Rentan \\
& berkerut & Gejala mosaik dengan ukuran daun mengecil dan \\
4 & berkerut serta menggulung & Sangat rentan \\
\end{tabular}


Tabel 2. Rerata Keparahan penyakit dan kategori ketahanan terhadap SMV pada populasi F4 kedelai

\begin{tabular}{clccc}
\hline No & \multicolumn{1}{c}{ Persilangan } & $\begin{array}{c}\text { Jumlah tanaman } \\
\text { terinfeksi/tanaman } \\
\text { yang diinokulasi }\end{array}$ & $\begin{array}{c}\text { Keparahan penyakit } \\
(\%)\end{array}$ & Tingkat ketahanan \\
\hline 1 & Wilis x L. Jombang & $14 / 50$ & 23,9 & Agak tahan \\
2 & Wilis x Mlg 3288 & $11 / 50$ & 20,4 & Agak tahan \\
3 & Wilis x L. Temanggung & $13 / 50$ & 20,5 & Agak tahan \\
4 & Wilis x Malabar & $16 / 50$ & 31,2 & Agak rentan \\
5 & Wilis x Pangrango & $7 / 50$ & 11,8 & Agak tahan \\
6 & Wilis x PI 200485 & $9 / 50$ & 15,5 & Agak tahan \\
7 & Wilis x M8Grb 44 & $11 / 50$ & 20,5 & Agak tahan \\
8 & Gepak Kuning x L. Jombang & $15 / 50$ & 30,1 & Agak rentan \\
9 & Gepak Kuning x Mlg 3288 & $0 / 50$ & 0,0 & Tahan \\
10 & Gepak Kuning x L. Temanggung & $18 / 50$ & 30,7 & Agak rentan \\
11 & Gepak Kuning x Malabar & $0 / 50$ & 0,0 & Tahan \\
12 & Gepak Kuning x Pangrango & $6 / 50$ & 10,2 & Agak tahan \\
13 & Gepak Kuning x PI 200485 & $3 / 50$ & 5,1 & Agak tahan \\
14 & Gepak Kuning x M8Grb 44 & $4 / 50$ & 6,9 & Rentan \\
15 & Wilis & $6 / 10$ & 51,1 & Agak rentan \\
16 & Gepak Kuning & $2 / 10$ & 27,1 & Tahan \\
17 & L. Jombang & $0 / 10$ & 0,0 & Tahan \\
18 & Mlg 3288 & $0 / 10$ & 0,0 & Tahan \\
19 & L. Temanggung & $1 / 10$ & 0,0 & Tahan \\
20 & Malabar & $0 / 10$ & 0,0 & Tahan \\
21 & Pangrango & $0 / 10$ & 0,0 & Tahan \\
22 & PI 200485 & $1 / 10$ & 0,0 & Tahan \\
23 & M8Grb 44 & $0 / 10$ & 0,0 & \\
\hline & & & & \\
\end{tabular}

(Wilis dan Gepak Kuning), masing-masing 9,06 g dan 9,16 g pada bobot 100 biji (Tabel 2 dan 3). Populasi F4 dari kombinasi persilangan Gepak Kuning x PI 200485 mempunyai jumlah cabang dan jumlah polong paling banyak serta bobot 100 biji (g) terbesar dibandingkan kombinasi persilangan yang lain. Ukuran biji berdasarkan bobot 100 biji dari kombinasi persilangan tersebut termasuk berukuran sedang $(10,29 \mathrm{~g} / 100 \mathrm{biji})$, menyerupai salah satu tetuanya (PI 200485) (Tabel 3). Bobot biji pertanaman memberikan informasi besarnya kemampuan tiap tanaman dalam menghasilkan biji.

Umur masak polong dari populasi $\mathrm{F} 4$ pada 14 persilangan berkisar antara 76,3-1 hari (Tabel 3). Adie (2007) mengelompokkan umur kedelai di Indonesia menjadi lima kelompok yaitu kedelai berumur sangat genjah ( $<70$ hari), genjah (70-80 hari), sedang (80-85 hari), dalam (86-90 hari), dan sangat dalam ( $>90$ hari). Berdasarkan pengelompokkan tersebut, maka populasi F4 pada 14 persilangan yang diuji dapat dikelompokkan ke dalam kelompok, yaitu berumur genjah (3 persilangan), sedang (6 persilangan), dalam 4 persilangan), dan sangat dalam (1 persilangan).

Kombinasi persilangan dari rata-rata populasi $\mathrm{F} 4$ Gepak Kuning x PI 200485 mempunyai hasil biji (ton/ ha) tertinggi dengan rata-rata 1,97 ton/ha serta jumlah polong hampa terendah. Meskipun jumlah polong hampa tersebut tidak berbeda nyata pada populasi Wilis x L. Temanggung. Hasil biji ini juga didukung oleh batang yang tinggi (tertinggi dibandingkan rata-rata populasi F4 yang lain), jumlah cabang pertanaman, jumlah polong dan bobot biji pertanaman. Jumlah polong isi menunjukkan kemampuan tanaman untuk menghasilkan biji. Daya hasil tinggi ditunjang oleh satu atau lebih sifat komponen hasil yang tinggi termasuk jumlah polong.

Hasil biji (ton/ha) ini diikuti oleh Gepak Kuning x Mlg 3288 dengan rata-rata 1,91 ton/ha, meskipun berbeda dengan Gepak Kuning x PI 200485 (1,97 ton/ha). Populasi F4 tersebut masing-masing memiliki kriteria tahan dan agak tahan terhadap SMV. Hasil biji terendah (ton/ha) dicapai oleh populasi Wilis x Malabar dengan 
Tabel 3. Sifat-sifat agronomi dan komponen hasil dari populasi F4 kedelai

\begin{tabular}{|c|c|c|c|c|c|c|}
\hline No & Persilangan & $\left.\mathrm{TT}^{*}\right)$ & $\mathrm{UM}^{*}$ & $\left.\mathrm{JP}^{*}\right)$ & $\mathrm{BSB}^{*)}$ & $\left.\mathrm{JC}^{*}\right)$ \\
\hline 1 & Wilis x L. Jombang & $55,2^{* *} \mathrm{c}-\mathrm{f}$ & 82,2 b-e & 35,0 b-f & 9,84 a-e & $3,43 \mathrm{~b}-\mathrm{d}$ \\
\hline 2 & Wilis x Mlg 3288 & 52,7 a-e & $88,1 \mathrm{~g}-\mathrm{i}$ & $27,5 \mathrm{ab}$ & $7,72 \mathrm{a}-\mathrm{c}$ & $2,00 \mathrm{a}$ \\
\hline 3 & Wilis $\mathrm{x}$ L. Temanggung & 49,8 a-d & $83,3 \mathrm{c}-\mathrm{f}$ & $34,7 \mathrm{~b}-\mathrm{f}$ & 9,58 a-e & $2,09 a-b$ \\
\hline 4 & Wilis x Malabar & 58,8 e-f & $79,5 \mathrm{a}-\mathrm{c}$ & $31,8 \mathrm{a}-\mathrm{e}$ & 8,09 a-d & 3,10 a-d \\
\hline 5 & Wilis x Pangrango & $58,1 \mathrm{e}-\mathrm{f}$ & $87,2 \mathrm{f}-\mathrm{h}$ & $31,9 a-f$ & $10,02 \mathrm{~b}-\mathrm{e}$ & 3,10 a-d \\
\hline 6 & Wilis x PI 200485 & 59,1 e-f & $85,7 \mathrm{~d}-\mathrm{g}$ & $27,3 a-b$ & $10,26 \mathrm{c}-\mathrm{e}$ & 3,27 a-d \\
\hline 7 & Wilis x M8Grb 44 & $54,6 \mathrm{c}-\mathrm{f}$ & 91,0 h-j & $40,8 \mathrm{f}-\mathrm{g}$ & 7,36 a-b & $2,19 a-b$ \\
\hline 8 & Gepak Kuning x L. Jombang & $47,3 \mathrm{a}-\mathrm{b}$ & 79,8 a-c & $35,6 \mathrm{c}-\mathrm{g}$ & $10,13 \mathrm{c}-\mathrm{e}$ & 3,10 a-d \\
\hline 9 & Gepak Kuning x Mlg 3288 & $56,1 \mathrm{c}-\mathrm{f}$ & 86,3 e-g & $53,4 \mathrm{~h}$ & 7,9 a-c & 3,21 a-d \\
\hline 10 & Gepak Kuning x L.Temanggung & $49,2 \mathrm{a}-\mathrm{c}$ & $81,7 \mathrm{~b}-\mathrm{d}$ & $33,5 a-f$ & 9,97 a-e & $2,23 \mathrm{a}-\mathrm{c}$ \\
\hline 11 & Gepak Kuning x Malabar & 52,9 a-d & $83,4 \mathrm{c}-\mathrm{f}$ & 29,1 a-d & 9,92 a-e & 2,70 a-d \\
\hline 12 & Gepak Kuning x Pangrango & $54,6 \mathrm{c}-\mathrm{f}$ & $83,6 \mathrm{c}-\mathrm{f}$ & $30,7 a-d$ & 9,14 a-e & $2,37 \mathrm{a}-\mathrm{d}$ \\
\hline 13 & Gepak Kuning x PI 200485 & $61,2 \mathrm{~g}$ & 76,3 a & $54,1 \mathrm{~h}$ & $10,29 \mathrm{~d}-\mathrm{e}$ & $3,61 \mathrm{c}-\mathrm{d}$ \\
\hline 14 & Gepak Kuning x M8Grb 44 & 52,4 a-d & 89,8 g-i & $43,2 \mathrm{~g}$ & 7,89 a-c & 2,70 a-d \\
\hline 15 & Wilis & $45,9 \mathrm{a}$ & $87,0 \mathrm{f}-\mathrm{h}$ & 28,7 a-c & 9,06 a-e & $2,08 \mathrm{a}-\mathrm{b}$ \\
\hline 16 & Gepak Kuning & 53,6 b-e & $78.2 \mathrm{a}-\mathrm{b}$ & $39,1 \mathrm{e}-\mathrm{g}$ & 9,16 a-e & 3,03 a-d \\
\hline 17 & L. Jombang & 53,4 a-d & $84,6 \mathrm{~d}-\mathrm{f}$ & $25,4 \mathrm{a}$ & $11,06 \mathrm{e}$ & $2,09 a-b$ \\
\hline 18 & Mlg 3288 & 58,0 e-f & $89,3 \mathrm{~g}-\mathrm{i}$ & $55,1 \mathrm{~h}$ & 7,24 a & $3,59 \mathrm{c}-\mathrm{d}$ \\
\hline 19 & L. Temanggung & $47,3 \mathrm{a}-\mathrm{b}$ & $85,6 \mathrm{~d}-\mathrm{g}$ & 39,3 e-g & 9,29 a-e & $3,71 \mathrm{~d}$ \\
\hline 20 & Malabar & 54,1 b-e & $83,4 \mathrm{c}-\mathrm{f}$ & 29,6 a-d & $10,98 \mathrm{e}$ & $2,08 \mathrm{a}-\mathrm{b}$ \\
\hline 21 & Pangrango & $49,5 \mathrm{a}-\mathrm{c}$ & $86,6 \mathrm{e}-\mathrm{g}$ & $37,1 \mathrm{~d}-\mathrm{g}$ & 8,42 a-e & $2,37 \mathrm{a}-\mathrm{d}$ \\
\hline 22 & PI 200485 & 57,2 e-f & 92,4 i-k & $25,6 \mathrm{a}$ & $11,12 \mathrm{e}$ & $1,93 \mathrm{a}$ \\
\hline \multirow[t]{2}{*}{23} & M8Grb 44 & $56,8 \mathrm{~d}-\mathrm{f}$ & $94,3 \mathrm{j}-\mathrm{k}$ & $29,7 a-d$ & 10,09 b-e & $2,17 \mathrm{a}-\mathrm{b}$ \\
\hline & BNT 5\% & 7,01 & 4,38 & 8,12 & 2,76 & 1,38 \\
\hline
\end{tabular}

*) $\mathrm{TT}=$ Tinggi tanaman (cm); UM = umur masak (hari); JP= jumlah polong/tanaman; $\mathrm{BSB}=$ Bobot $100 \mathrm{biji}(\mathrm{g})$; JC= Jumlah cabang/tanaman; $\left.{ }^{* *}\right)$ Angka yang diikuti huruf yang sama pada kolom yang sama menunjukkan tidak berbeda nyata pada taraf $5 \%$

rata-rata 1,49 ton/ha dengan keparahan penyakit tertinggi $(31,23 \%)$ serta jumlah polong hampa tidak berbeda nyata dengan populasi Gepak Kuning x L. Temanggung dengan keparahan penyakit $30,65 \%$ terhadap SMV (Tabel 4). Varietas Gepak Kuning yang digunakan sebagai pembanding memiliki hasil biji ratarata 1,986 ton/ha, tidak berbeda nyata dengan populasi Gepak Kuning x PI 200485, meskipun Gepak Kuning pada bobot seratus biji lebih rendah dan keparahan penyakit lebih tinggi serta umur masak polong lebih lama.

Tiga populasi berumur genjah kurang dari 80 hari dalam persilangan, tetapi yang mempunyai kategori agak tahan hanya satu populasi yaitu Gepak Kuning x PI 200485 dengan rata-rata berumur 76,3 hari. Hal ini yang menyebabkan sulitnya mendapat kedelai berdaya hasil di atas 1,97 ton/ha dengan umur masak di bawah 80 hari. Populasi dari kombinasi persilangan tersebut memiliki keunggulan berumur genjah. Oleh karena itu persilangan ini mempunyai salah satu mekanisme penghindaran (escape) untuk mempertahankan potensi hasil terhadap SMV, sehingga penurunan hasil akibat infeksi SMV dapat dieliminir.

Rata-rata populasi F4 dari 14 kombinasi persilangan diperoleh dua populasi tanaman kedelai sebagai galur-galur harapan untuk pengembangan selanjutnya. Populasi yang memberikan hasil biji tertinggi adalah Gepak Kuning x PI 200485, dan keparahan penyakit 5,11\% dengan kategori agak tahan. Selanjutnya hasil biji ini diikuti Gepak Kuning x Malabar yang memiliki keparahan penyakit $0 \%$ dengan kriteria tahan, tetapi hasil biji tergolong rendah, sehingga populasi ini tidak termasuk untuk populasi pilihan yang mempunyai kriteria agronomis baik (Tabel 4). Nilai ekonomis kedelai ditentukan oleh kemampuan produksi dan peluang untuk dipadukan dengan karakter lain, misalnya bobot seratus biji, umur genjah dengan kategori ketahanan sangat ringan terhadap SMV. 
Tabel 4. Rata-rata jumlah polong hampa dan komponen hasil (t/ha) dari populasi F4 kedelai

\begin{tabular}{lllc}
\hline No & Persilangan & JPH $^{*}$ & Hasil biji (t/ha $)^{*}$ \\
\hline 1 & Wilis x L. Jombang & $1,8 \mathrm{a}-\mathrm{c}$ & $1,56 \mathrm{a}-\mathrm{c}$ \\
2 & Wilis x Mlg 3288 & $1,9 \mathrm{a}-\mathrm{d}$ & $1,65 \mathrm{c}-\mathrm{e}$ \\
3 & Wilis x L. Temanggung & $1,5 \mathrm{a}$ & $1,52 \mathrm{a}-\mathrm{b}$ \\
4 & Wilis x Malabar & $1,8 \mathrm{a}-\mathrm{c}$ & $1,49 \mathrm{a}$ \\
5 & Wilis x Pangrango & $1,6 \mathrm{a}-\mathrm{b}$ & $1,54 \mathrm{a}-\mathrm{c}$ \\
6 & Wilis x PI 200485 & $1,9 \mathrm{a}-\mathrm{d}$ & $1,63 \mathrm{~b}-\mathrm{d}$ \\
7 & Wilis x M8Grb 44 & $1,6 \mathrm{a}-\mathrm{b}$ & $1,57 \mathrm{a}-\mathrm{d}$ \\
8 & Gepak Kuning x L. Jombang & $2,4 \mathrm{~d}-\mathrm{e}$ & $1,81 \mathrm{~g}-\mathrm{h}$ \\
9 & Gepak Kuning x Mlg 3288 & $2,2 \mathrm{c}-\mathrm{e}$ & $1,91 \mathrm{~h}-\mathrm{i}$ \\
10 & Gepak Kuning x L. Temanggung & $1,8 \mathrm{a}-\mathrm{c}$ & $1,68 \mathrm{~d}-\mathrm{f}$ \\
11 & Gepak Kuning x Malabar & $1,6 \mathrm{a}-\mathrm{b}$ & $1,62 \mathrm{~b}-\mathrm{d}$ \\
12 & Gepak Kuning x Pangrango & $2,0 \mathrm{a}-\mathrm{d}$ & $1,65 \mathrm{c}-\mathrm{e}$ \\
13 & Gepak Kuning x PI 200485 & $1,5 \mathrm{a}$ & $1,97 \mathrm{i}$ \\
14 & Gepak Kuning x M8Grb 44 & $1,8 \mathrm{a}-\mathrm{c}$ & $1,79 \mathrm{f}-\mathrm{g}$ \\
15 & Wilis & $1,9 \mathrm{a}-\mathrm{d}$ & $1,58 \mathrm{a}-\mathrm{d}$ \\
16 & Gepak Kuning & $1,5 \mathrm{a}$ & $1,96 \mathrm{i}$ \\
17 & L. Jombang & $2,9 \mathrm{f}$ & $1,76 \mathrm{e}-\mathrm{g}$ \\
18 & Mlg 3288 & $2,6 \mathrm{e}-\mathrm{f}$ & $1,84 \mathrm{~g}-\mathrm{h}$ \\
19 & L. Temanggung & $2,4 \mathrm{~d}-\mathrm{f}$ & $1,59 \mathrm{a}-\mathrm{d}$ \\
20 & Malabar & $2,2 \mathrm{c}-\mathrm{e}$ & $1,53 \mathrm{a}-\mathrm{b}$ \\
21 & Pangrango & $1,9 \mathrm{a}-\mathrm{d}$ & $1,61 \mathrm{a}-\mathrm{d}$ \\
22 & PI 200485 & $1,7 \mathrm{a}-\mathrm{c}$ & $1,80 \mathrm{~g}-\mathrm{h}$ \\
23 & M8Grb 44 & $2,1 \mathrm{~b}-\mathrm{e}$ & $1,81 \mathrm{~g}-\mathrm{h}$ \\
\hline & BNT 5\% & 0,54 & 0,11 \\
\hline
\end{tabular}

*) Angka yang diikuti huruf yang sama pada kolom yang sama menunjukkan tidak berbeda nyata pada taraf 5\%; JPH: Jumlah polong hampa/tanaman.

\section{SIMPULAN}

Dari hasil penelitian ini dapat disimpulkan bahwa: (1) populasi F4 dengan hasil biji tertinggi (1,97 ton/ha) adalah Gepak Kuning x PI 200485, termasuk kriteria agak tahan terhadap SMV (keparahan penyakit 5,11\%) dengan rata-rata bobot biji sedang (10,26 g/199 biji), jumlah cabang terbanyak $(3,61)$ dan jumlah polong terbanyak 54,1 ; (2) populasi F4 pada Gepak Kuning x Mlg 3288 mempunyai hasil biji yang tidak berbeda nyata dengan Gepak Kuning x PI 200485 (1,91 ton/ha) dan termasuk kriteria tahan terhadap SMV (keparahan penyakit $0 \%$ ), walaupun karakter agronomi lebih rendah dibandingkan dengan Gepak Kuning x PI 200485, terutama pada rata-rata bobot biji kecil $(7,91 \mathrm{~g} / 100 \mathrm{biji})$, jumlah cabang $(3,21)$, dan jumlah polong 53,4 dan (3) galur-galur dari Populasi F4 pada Gepak Kuning x PI 200485 dan Gepak Kuning x Mlg 3288 mempunyai peluang untuk dikembangkan menjadi varietas unggul kedelai tahan SMV dan berdaya hasil tinggi.

\section{DAFTAR PUSTAKA}

Adie MM. 2007. Panduan pengujian individual, kebaruan, keunikan, keseragaman dan kestabilan kedelai. Pusat Perlindungan Varietas Tanaman. Departemen Pertanian Republik Indonesia.

Adie MM \& Krisnawati A. 2013. Keragaman dan seleksi hasil biji dari galur-galur kedelai generasi lanjut. Dalam: Patiwi H \& Winarto A(Eds.). Prosiding Seminar Nasional Hasil penelitian Tanaman Aneka Kacang dan Umbi. pp. 19-26. Pusat Penelitian dan Pengembangan Tanaman Pangan. Badan Penelitian dan Pengembangan Pertanian, Bogor.

Andayanie WR, Sumardiyono YB, Hartono S, \& Yudono P. 2011a. Incidence of soybean mosaic disease in East Java Province. J Agrivita 33(1): 15-22. 
Andayanie WR, Sumardiyono YB, Hartono S \& Yudono P. 2011b. Identifikasi dan pengelolaan virus mosaik kedelai terbawa benih Disertasi. Universitas Gadjah Mada, Yogyakarta.

Andayanie WR. 2012a. Penyakit mosaik kedelai dan pengelolaan Soybean Mosaic Virus terbawa benih. Dalam: Winarto A \& Sari KP. (Eds.). Prosiding Seminar Nasional Hasil Penelitian Tanaman Aneka Kacang dan Umbi. pp. 33347.Pusat Penelitian dan Pengembangan Tanaman Pangan. Badan Penelitian dan Pengembangan Pertanian, Bogor.

Andayanie WR. 2012b.Diagnosis penyakit mosaik (Soybean Mosaic Virus) terbawa benih kedelai. J HPT Tropika 12(2): 185-191.

Andayanie WR \& Adinurani PG. 2013a. Evaluasi genotipe kedelai [Glycine max (L.) Merr.] tahan terhadap mosaic virus. Makalah Seminar dan Kongres Nasional Ke XXII Perhimpunan Fitopatologi Indonesia. Padang 7-10 Oktober 2013.

Andayanie WR \& Adinurani PG. 2013b. Ketahanan dan pemuliaan kedelai [Glycine max (L.) Merrill] terhadap virus mosaik (Soybean Mosaic Virus) berdaya hasil tinggi. Laporan akhir. Penelitian Hibah Strategis Nasional Tahun I. Direktorat Penelitian dan Pengabdian kepada Masyarakat. Dirjen Dikti. Kementerian Pendidikan dan Kebudayaan.

Arifin AS. 2013. Kajian morfologi anatomi dan agronomi antara kedelai sehat dan kedelai terserang Cowpea Mild Mottle Virus serta pemanfaatannya sebagai bahan ajar Sekolah Menengah Kejuruan. Jurnal Pendidikan Sains 1(2): 115-125.

Asadi, Soemartono, Mangoendidjojo W, \& Harjosudarmo J. 2005. Genetika ketahanan dan pemuliaan kedelai [Glycine max (L.)] terhadap virus kerdil (Soybean Stunt Virus). Disertasi. Universitas Gadjah Mada Yogyakarta.

Asadi \& Dewi N. 2010. Identifikasi sumber daya genetik kedelai tahan penyakit virus kerdil kedelai. Buletin Plasma Nutfah 16(2): 107-112.

Badan Pusat Statistik. 2013. Produksi padi, jagung, dan kedelai (Angka Sementara Tahun 2013). Berita Resmi Statistik. No 22/03/Th XVII, 3 Maret 2014.
Balitkabi. 2012. Pemuliaan kedelai di Korea Selatan. Science innovation.network. http:// www.balitkabi.litbang.deptan.go.id. Diakses tanggal 11/04/2014.

Barmawi M, Utomo SD, Akin HM, \& Romli S. 2009. Uji ketahanan terhadap Cowpea Mild Mottle Virus pada sembilan belas populasi $\mathrm{F}_{1}$ tanaman kedelai [Glycine max (L.) Merril] hasil persilangan dialel. Agrotropika 14(2): 81-85.

Campbell CL \& Madden LV. 1990. Introduction to Plant Disease Epidemiology. Mc. Millan Publishing Co. Inc, New York.

Chen J, Chen JP \& Adam MJ. 2001. A universal PCR primer to detect members of the Potyviridae and its use to examine the taxonomic status of several members of the family. Arch. Virol. 146(4): 757766.

Erliana G. 2010. Mutu kedelai nasional lebih baik dari kedelai impor. Berita Puslitbangtan 45. November 2010. Hal. 17.

Hwang TY, Soon CJ, Oksun K, Hyang MP, Seuk KL, Min JS, Man SC, Yu Yl, Young UK, Wook HK, \& Yul HK. 2011. Intra host competition and interaction between Soybean Mosaic Virus (SMV) strains in mixed infected soybean. Aust. Crop Sci. 5(11): 1379-1387.

Kim YH, Kim OS, Roh JH, Moon JK, Sohn SI, Lee SC, \& Lee JY. 2004. Identification of Soybean Mosaic Virus strains by RT-PCR/RLFP analysis of cylindrical inclusion coding region. Plant Dis. 88(6): 641-644.

Ma G, Chen P, Buss GR, \& Tolin SA. 2004 . Genetic of resistance to two strains of Soybean mosaic virus in differential soybean genotypes. $J$. Hered. 95(4): 322-326.

Pusat Penelitian dan Pengembangan Tanaman Pangan. 2010. Kedelai genjah Gepak Kuning dan Gepak Ijo. Laporan Informasi Ringkas bank Pengetahuan Tanaman Pangan Indonesia.

Somowiyarjo S. 2004. Pengembangan Serodiagnosis Virus Tumbuhan untuk Mendukung Kemandiran Pangan. Pidato Pengukuhan Jabatan Guru Besar dalam Ilmu Penyakit Tumbuhan. Fakultas Pertanian UGM. 20 Maret 2004. 